\title{
The Use of Passivity Strategies in a Group of 10-12 Year-old Pupils from the Perspective of Transactional Analysis
}

\author{
Anna Pierzchała \\ Jan Dlugosz University, Faculty of Pedagogy, Institute of Pedagogy, Educational Transactional Analysis Research Team, \\ Waszyngtona St. 4/8, 42-200, Czestochowa, Poland, a.pierzchala@ujd.edu.pl
}

\begin{abstract}
The article shows the results of the research that characterises passivity in the environment of Polish school youth following the assumptions of one of psychotherapeutic concepts - transactional analysis. Passivity should be understood hereas a lack of efficiency in dealing with a problematic situation, which may manifest itself in several strategies. Conclusions concern the scale of the phenomenon, the scope of the use of the respective strategies and the search for the reasons in the area of family relations.
\end{abstract}

Keywords: transactional analysis, passivity, doing nothing, overadaptation, agitation, incapacitation, violence.

\section{Introduction}

The contemporary school, both in Poland and around the world, faces many social and economic difficulties, which decrease its effectiveness and negatively affect the quality of its educational activities (Widawska, 2016). Passivity belongs to social problems that influence broad areas of pedagogical activity, including the student-teacher relationship. This phenomenon can be perceived as a significant barrier hindering, or even preventing, an effective implementation of educational goals. Therefore, the topic of passivity is increasingly addressed by people involved in didactic and educational activities, mainly by teachers, who often complain about lack of activity on the part of their students and indicate the need for continuous stimulation and control of activities undertaken by them. 
In the present article, the topic of school passivity will be discussed from the perspective of transactional analysis /TA/,which constitutes one of the branches of contemporary psychology and psychotherapy.

\section{Transactional analysis and passivity - theoretical background of the research}

Initially, the concept was understood as the "theory of personality and systematic psychotherapy for personal growth and personal change" (Stewart, Joines, 2009). Thereafter, already in the 1960s, its assumptions began to be transferred to other areas of human functioning, including education. The contributions of S. Soles (1963), T. Frazier (1971) and J. I. Clarke (1981) were significant in this area. Moreover, the educational focus of the concept has been officially confirmed - in 1982, the International Transactional Analysis Association (ITAA) and the European Association for Transactional Analysis (EATA) adopted a resolution on giving certificates in the field of educational transactional analysis (Emmerton, Newton, 2004). The main goals of educational transactional analysis encompass the possibilities of drawing inspiration from psychotherapy in the research and analyses of broadly understood education (Jagieła, 2018).

The assumptions rooted in educational transactional analysis and used in educational practice relate to the greatest extent to human resources, and are based on peoples' positive sides. Thus, this concept is close to pedagogy rooted in humanistic psychology in the version of person-centered therapy by C. Rogers, A. Maslow as well as F. Perls' psychotherapy and Gestalt pedagogy. Nonetheless, TA mainly emphasises emotional self-understanding, focusing more on the rational and intellectual side of students' functioning, which distinguishes it from the Gestalt approach (James, Jongeward, 2003). At the same time, both Gestalt pedagogy and educational transactional analysis account for a systematic approach to human functioning in their assumptions. First of all, they both refer to the student's physicality, psyche and spirituality. Secondly, they try to treat pupils not only in accordance with their role as students, but also with other roles performed outside school. Ch. Sills, S. Fish and P. Lapworth (1999), indicate that holism is understood here as a necessity for a holistic and integrated recognition of experiences instead of dividing them into distinguishable fragments.

At present, educational transactional analysis is successfully used in practical activities of schools, kindergartens and various educational centres. There is a noticeable increase in interest in transactional analysis in Eastern Europe, including Poland, and even in Japan and India (Emmerton, Newton, 2004). However, in Western Europe and the United States there is the largest number of training centres for TA educators. The effects of work based on the assumptions of educational transactional analysis are described in S. Gaft, C. Moore Brown El (2004) and G. Barrow (2007). We can also read about practical 
achievements of educational transactional analysis in various publications which show possibilities of using TA in education and upbringing. Many of such publications have been issued over the years. If we limit ourselves to those published in the 21st century, it is possible to indicate the ones which are most important from the perspective of the present study: Improving Behaviour and Raising Self-Esteem in the Classroom. A Practical Guide to Using Transactional Analysis (Barrow, Bradshaw, Newton, 2001), Walking the Talk. How transactional analysis is improving behaviour and raising self-esteem (Barrow, Newton (eds.), 2004), Educational Transactional Analysis: An international guide to theory and practice (Barrow, Newton, 2015).

Researchers have attempted to determine the usefulness of the transactional analysis assumptions for education. M. Lerkkanen and S. Temple (2004, pp. 253-271) conducted international research (Finland, Great Britain) concerning opinions of future teachers on the importance and possibilities of using knowledge in the field of TA. They indicated a significant value of this concept. D. Gębuś and A. Pierzchała (2016) were analysing teachers' personality in terms of their competences for developing a creative attitude of the student. Z. Łęski $(2016 ; 2018)$ pointed to the importance of transactional analysis in education that was using new technologies.

The passivity phenomenon included in the title of the article and understood from the perspective of transactional analysis is one of those issues, whose assumptions have already been successfully used in the field of school education, where the concept has been examined and its importance has been established by research (Pierzchała, 2013). However, it should be emphasized that the term "passivity" is understood here slightly differently than traditionally, since the creators of this concept in transactional analysis,Jaqui L. Schiff and Aaron W. Schiff (1971), drew attention to the fact that people, throughout their lives, constantly face different problem situations. Every situation which forces an individual to make a decision concerning the mode of action is treated as problematic(Stewart, Joines, 2009), and passivity is a way of thinking and behaving that allows an individual to avoid an autonomous response in the case of difficulties (Schiff, 1975). Thus, it is essential that, in contrast to the traditional understanding of passivity, which identifies it with a lack of action, transactional analysis perceives it as a situation in which an individual ceases to perform specific activities or performs them in an ineffective way (Schiff, 1975). This means that a passive person can perform certain actions, but they are ineffective from the point of view of the assumed goals. Passivity understood in this way can manifest itself through five strategies placed on a scale of destructiveness.

The first involves doing nothing and is closest to the traditional meaning of passivity. It entails a lack of taking action in the case of a problem. When faced with the need to make a difficult decision, people give up, do not take any action and wait for a reaction of the surroundings.

The second strategy, overadaptation, is a way of functioning in which a passive person tries to guess and meet other people's expectations concerning the activity. It is necessary 
to realise that it is an extremely convenient strategy because the person seems to be realising the goals set for him or her. For this reason, the strategy is often enhanced by the environment. However, it is crucial that the realisation of goals is not based on an inner conviction about their value and legitimacy. Subsequently, long-term use of this kind of passivity causes that people become externally controlled, they cannot determine the way of acting and cannot recognize their own needs by themselves. Overadaptation is particularly disadvantageous for young people who are just learning to function in the world because, in their case, this manner of acting is very likely to become permanent.

Agitation, which is another passivity strategy, appears in a situation, where the tension associated with the sense of inefficiency increases to such an extent that it should be quickly defused. In such a situation a passive person creates an appearance of action by starting to perform a series of schematic, repetitive activities, which, however, do not solve the problem. Hence, these activities do not lead to a solution (they are not aimed at the goal) but only slightly reduce unpleasant feelings associated with the emerging tension.

Finally, the last passive strategy has two different manifestations, which rely on the same formation mechanism. They are violence and incapacitation. The first of them is directed "outside" and the other "inside". Both become active when the tension appearing in people in the case of a problem is so high that it must find an outlet immediately. Depending on the dominant psychological structure, some people react with an act of aggression directed at something or someone in the environment, and some "immobilize" themselves from action through psychosomatic symptoms or self-aggression, whose extreme indicator is an act of suicide.

The described strategies show that, according to transactional analysis, passivity can manifest itself not only in the lack of any action. Its characteristic feature is an attempt of a person who cannot cope with a problem to transfer responsibility to the environment.

Moreover, in order to complement the theoretical basis of the research described in the further part of the article, it should be indicated that every human activity analysed in terms of transactional analysis (thinking / feeling / acting) is realised from a specific ego state (Stewart, Joines, 2009). The same fact applies to passivity. E. Berne, the creator of TA, claims that the focus of interest of transactional analysis lies in the study of ego states, the coherent systems of thoughts and feelings, which are manifested by appropriate sets of behaviours (Berne, 2005). In his opinion, an ego state can be described "phenomenologically as a coherent system of feelings related to a given subject, and operationally as a set of coherent behaviour patterns; or pragmatically, as a system of feelings which motivates a related set of behaviour patterns" (Berne, 2008). Thus, thoughts and feelings constitute the basis for distinguishing ego states. The transactional analysis distinguishes three basic states: the Parent ego-state, the Adult ego-state and the Child ego-state (Stewart, Joines, 2009).

The Child constitutes the most original ego state. It is a way of thinking and feeling that derives from the period of early childhood. Within this state, the Free Child and the 
Adapted Child can be distinguished. The former constitutes the most original part of human personality, while the Adapted Child is a part of personality which has learned to respond to social expectations. In the context of the Free Child, the so-called Little Professor, the most intuitive ego part of a person, can be differentiated.

The Parent ego-state involves a person's way of existence which was adopted on the basis of early messages from significant people, mainly parents. Therefore, it is a way of thinking, feeling and acting, which is automatically adopted in early childhood on the basis of parental modelling (Stewart, Joines, 2009). Within the Parent area, we can distinguish the Controlling Parent, which comprises a system of parental prohibitions and orders, and the Nurturing Parent, which encompasses nurturing instincts.

In contrast, the Adult ego-state is the most rational part of human personality. It provides an opportunity to analyse reality without using "filters" of early childhood conditioning. Therefore, it enables autonomous thinking and taking independent decisions concerning legitimacy of a specific action. Passivity, which this study addresses, is not realised from the Adult level because this ego state would require confrontation with the ineffectiveness of this phenomenon. The areas of the Parent and the Child constitute the basis of passivity. Thus, the way out of it requires activation of thinking, feeling, and, consequently, acting from the Adult level (Schiff, 1975).

\section{Own research concerning passivity phenomenon among learners}

\section{Research methodology}

Passivity understood in this way has become the topic of own research, whose results will be presented below. The analysis of the passivity phenomenon among students constituted a part of an extensive research project titled "Raising a wise man. Introducing a model of education and resocialization work with the use of the school tutoring method as positive prevention of problems in the Polish school".It was financed by the Polish Ministry of National Education and realised between November 2016 and December 2018 by the Open Education Society (http://teo.org.pl/) in cooperation with Jan Dlugosz University in Czestochowa. The general goal of the project involved implementing the model of work that would prevent social exclusion through identifying problems early and, if necessary, taking actions to reintegrate students into society and move them out of a crisis situation with a perspective of success (see http://www.tutoringszkolny. $\mathrm{pl} / \mathrm{o}$-projekcie).

The Educational Transactional Analysis Research Team at Jan Dlugosz University in Czestochowa was responsible for evaluating the implementation. The research was carried out throughout Poland in selected primary, middle and high schools. The method of a diagnostic survey based on the questionnaire technique was used. The tools employed in 
the research were developed by the Educational Transactional Analysis Research Team functioning at the Faculty of Pedagogy of theJan Dlugosz University in Czestochowa.

The research was performed in an electronic form with the use of a platform processing electronic questionnaires based on LimeSurvey system and available under the following internet address: https://wp.udj.edu.pl/ankiety.In total, 9576 students took part in the project (Sarnat-Ciastko, Gębuś, Zalewski, 2018).

The research goal of the present study is to determine the scale of the occurrence of the passivity phenomenon (together with an indication of its strategies) understood in accordance with the assumptions of transactional analysis among Polish school students, taking into account the gender variable. Primary school students of the 4 th grade (10-11 year-olds) ${ }^{1}$ and the 5 th grade (11-12 year-olds) participated in the research and the scope of their passivity use was determined.This is the first research stage, which means that the obtained data concerning the period before the implementation of the work model assumed in the project. The data were collected in October 2017.

A randomly selected research sample consisted of 2172 learners, of which 1126 were girls, and 1046 were boys.The research sample has been characterised in more detail in Table 1.

Table 1

Characteristics of the research sample

\begin{tabular}{|c|c|c|c|}
\hline \multirow{2}{*}{ SEX } & \multicolumn{2}{|c|}{ Grade } & \multirow{2}{*}{ TOTAL } \\
\hline & Four & Five & \\
\hline Girls & 734 & 392 & 1126 \\
\hline Boys & 666 & 380 & 1046 \\
\hline TOTAL: & 1400 & 772 & 2172 \\
\hline
\end{tabular}

The rationale for choosing the age group of the research sample involved a desire to eliminate passivity conditioning resulting from the shape of the educational system. Simultaneously, the existence of sources of passive behaviours in families and their educational influences was hypothesised, which is consistent with the assumptions of the transactional analysis concept. Therefore, it was necessary to select a sample in such a way that, on the one hand, the participants of the research would function in the education system for a relatively short time, but on the other hand, they would be mature enough to be able to complete the questionnaire determining the scope and type of passivity employed by them. Thus, it was decided that the best moment for this type of analysis would be the threshold of the second education stage. In the Polish education system,

1 It should be noted that in the current Polish educational system, children start school education at the age of 6 or 7 . Hence, the indicated age range of the research participants. 
passing to grade 4 is associated with the transition to a typical subject education system. Grades 1-3 constitute an integrated learning stage, which implies that children participate in classes involving the so-called early school education without any specific theme and time frame. Lessons are taught mainly by one teacher, who also takes care of the group. Since the assessment is solely descriptive, children do not get numerical marks. The transition to the next stage of education (grade 4) is connected, on the one hand, with students' participation in lessons focused on a given area of knowledge (subjects), on the other, with the assessment system typical for Polish education (students are assessed on a scale, where 6 is excellent and 1 - unsatisfactory).

The research was based on the proprietary questionnaire "My teachers and I" created by the Educational Transactional Analysis Research Team. Itallows both for the determination of the scope of passive strategy use by students and for the implementation of specific aspects of their creative attitude ${ }^{2}$. The tool was designed by Anna Pierzchała, PhD and Dorota Gębuś, PhD. The questionnaire is based on the Likert scale. It is encoded in such a way that the result for a given category ranges from 0 to 15 . The selection of nonparametric statistics was conditioned by the nature of the scale used in the questionnaire (Likert scale), which adopts the ordinal character. The tool consists of 30 items and is at the disposal of the Educational Transactional Analysis Research Team. Table 2 presents the overall structure of the tool and a few exemplary items ${ }^{3}$.

Table 2

A fragment of the questionnaire "My teachers and I" (A. Pierzchała, D. Gębuś)

Below there are a few statements concerning the school and relations with the teachers. Please, state to what extent these statements are true for you. Mark your answers with the " $X$ " symbol in the appropriate box in the table.

\begin{tabular}{llllllll}
\hline \multicolumn{1}{c}{ STATEMENTS } & Yes & $\begin{array}{c}\text { Rather } \\
\text { yes }\end{array}$ & $\begin{array}{c}\text { Don't } \\
\text { know }\end{array}$ & $\begin{array}{c}\text { Rather } \\
\text { not }\end{array}$ & No \\
\hline $\begin{array}{l}\text { 1. I like when the teacher gives us tasks that can be } \\
\text { solved in various ways. }\end{array}$ & {$[\ldots]$} & {$[\ldots]$} & {$[\ldots]$} & {$[\ldots]$} & {$[\ldots]$} \\
\hline $\begin{array}{l}\text { 2. Sometimes I do not have the strength to do what } \\
\text { the teacher expects from me, so I don't do anything. }\end{array}$ & {$[\ldots]$} & {$[\ldots]$} & {$[\ldots]$} & {$[\ldots]$} & {$[\ldots]$} \\
\hline 3. I like topics which provoke a discussion. & {$[\ldots]$} & {$[\ldots]$} & {$[\ldots]$} & {$[\ldots]$} & {$[\ldots]$} \\
\hline $\begin{array}{l}\text { 4. Sometimes I get so nervous at school that I have } \\
\text { to do something different than a lesson because I } \\
\text { have a feeling that I can't take this anymore. }\end{array}$ & {$[\ldots]$} & {$[\ldots]$} & {$[\ldots]$} & {$[\ldots]$} & {$[\ldots]$} \\
\hline
\end{tabular}

2 In the case of this study, only the results concerning passivity have been taken into account

3 The full version of the questionnaire was published in: A. Sarnat-Ciastko, D. Gębuś, and Z. Zalewski (2018). „Wychować człowieka mądrego”. Raport końcowy z badań ewaluacyjnych ogólnopolskiego projektu wdrażania tutoringu szkolnego. (English: "Bring up a wise man." Final report on evaluation studies of a nationwide school tutoring implementation project. Częstochowa: StanisławPodobiński Publishing Company of the Jan Długosz University of Humanities and Natural Sciences in Częstochowa. The basic language version of the questionnaire is Polish. 
At the same time, the data were analysed using the $W$ Shapiro-Wilk test, which indicated that the null hypothesis, assuming the normality of the variable distribution, had to be rejected $(\mathrm{W}=0.97230, \mathrm{p}=0.0000)$. The variables do not have a normal distribution, which disqualifies them for the use of parametric tests.

The proper research was preceded by the verification of the questionnaire. Its accuracy and reliability were assessed by a team of experts, which consisted of people from academic units who know and use the assumptions of transactional analysis in practice. The Alpha Cronbach coefficient for the whole questionnaire and individual subscales was also determined (Table 3). Additionally, the conducted pilot studies assessed children's understanding of individual items. Based on preliminary analyses, there were some modifications of the number and sentence structure of some items.

Table 3

\begin{tabular}{lcc}
\begin{tabular}{lc} 
Reliability of the questionnaire "My teachers and I" (A. Pierzchała, D. Gębuś) \\
\hline Passive strategy
\end{tabular} & $\begin{array}{c}\text { a-Cronbach } \\
\text { (individual strategies) }\end{array}$ & $\begin{array}{c}\text { a-Cronbach } \\
\text { (passivity-whole questionnaire) }\end{array}$ \\
\cline { 1 - 2 } Doing nothing & 0.65 & \\
\hline Overadaptation & 0.63 & 0.87 \\
\cline { 1 - 2 } Agitation & 0.70 & \\
\hline Violence & 0.79 & \\
\hline Incapacitation & 0.74 & \\
\hline
\end{tabular}

The principles of ethics in this type of analysis were accounted for during the process of creating the research tool as well as the stage of research implementation. Firstly, as it has already been mentioned above, the tool was subjected to the opinion of external competent judges - psychologists and pedagogues, academic teachers.Their expert judgement also included the legitimacy and possibilities of using the questionnaire in the study of underage students (children and adolescents). The shape of the tool - its intelligibility and relevance to the school reality - was also determined by pedagogues, who were practitioners performing everyday work with schoolchildren and who were involved the pilot study concerning the appropriateness of the tool. On the basis of the obtained assessments of competent judges, pilot study results and consultations with practitioners, the draft versions of the tools were verified by introducing the suggested changes, which improved them in terms of methodological validity and reliability, as well as accessibility and readability for the respondents (Sarnat-Ciastko, Gębuś, Zalewski, 2018 ). At the same time, the students who participated in the research were guaranteed anonymity (only school membership and the level of education were indexed). Prior to conducting the research, the consent of legal guardians of the underage pupils had been obtained. The data collection process was coordinated by teachers from schools involved 
in the project and took place at the students' schools, which guaranteed a sense of security for the respondents.

The applied research proceduresand the presented tool allow for answering the following questions:

1. What is the scope of using transactional passiveness by Polish students starting the second stage of education?

2. What are the gender differences in the use of passive strategies?

3. Are there any differences in the use of passive strategies between students of grades 4 and 5 ? What are these differences?

\section{Analysis of the research results}

The analysis of the research results starts with a summary of the degree to which the learners employ passive strategies. Table 4 shows a comparison of the use of different passive strategies.

Table 4

The scope of the learners' passive strategy use - descriptive statistics (N=2172)

\begin{tabular}{|c|c|c|c|c|c|}
\hline \multirow[b]{2}{*}{ Passive strategy } & \multicolumn{5}{|c|}{ Desriptive statistics } \\
\hline & Mean & Median & Mode & Size of mode & $\begin{array}{l}\text { Standard } \\
\text { deviation }\end{array}$ \\
\hline Doing nothing & 7.79 & 7 & 7 & 327 & 3.06 \\
\hline Overadaptation & 8.43 & 8 & 9 & 314 & 2.94 \\
\hline Agitation & 7.66 & 7 & 3 & 291 & 3.46 \\
\hline Violence & 6.68 & 6 & 3 & 457 & 3.33 \\
\hline Incapacitation & 6.93 & 7 & 3 & 365 & 3.22 \\
\hline
\end{tabular}

As can be seen, the respondents have recognized all the passive strategies enumerated in the concept of transactional analysis in their functioning and they apply them to a moderate extent. Medians range from 6 to 7 , and modes indicate a significant variation in the use of passive strategies.

It can be observed that the dominant strategy is overadaptation (mean 8.43 , median 8 , mode 9). Since it is the passive strategy placed as the second on the scale of destructiveness, its level of destructiveness is relatively low for the person using it, which is due to a relatively lowtension level that accompanies it. However, it should be remembered that overadaptation brings with it certain long-term consequences, especially if it is used by children. As a well-established attitude, it causes lack of ability to independently establish goals, recognize one's own needs and independently determine the best path for oneself. 
People who use this strategy become vulnerable to the influence of others, including manipulation. In addition, lack of the ability to listen to yourself, concentrate on signals flowing from the body, on your own needs, cause difficulties in achieving life satisfaction and in entering into satisfying relationships with other people.

The remaining passive strategies enumerated according to the transactional analysis concept also have their manifestations in the functioning of the research subjects. However, it is consoling that doing nothing ranked second after overadaptation (mean 7.79, median 7, mode 7) since it is the mildest strategy in terms of destructiveness for the person using it. At the same time, it is easy to observe by other people. A way to remove or minimize this strategy in human functioning involves removing the so-called discounting, which entails disregarding or minimizing the meaning of certain facts from reality connected withsituations, other people or oneself (Mellor, Schiff, 1975; Schiff, 1974). Such discounting makes it difficult for a person to find a satisfactory way out of the situation. On the other hand, removal of discounters favours a real view of the reality, problems and possibilities of overcoming them.

The respondents recognized agitation in their functioning in a similar range, as indicated by the mean 7.66 and the median 7. It can be observed that, in this case, the value of the mode constitutes only 3 , which means that the distribution of the results rotates more to the left. The scope of agitation use in the studied group is therefore lower than in the case of overadaptation and doing nothing, which is a consoling fact because this strategy is further on the continuum of destructiveness than the previous two. Its use has consequences in the form of neurotic disorders, school phobias, etc. In addition, transactional analysis assumes that agitation is a transitional strategy, which means that it is not possible to function within it for a longer period of time. Although passive people are aware of the need to take action, they simultaneously have a sense of inadequacy and lack of competence (Schiff, 1975). Sending a firm and calm message "Sit down and think it over!" usually restores overadaptation. However, if such a message is not given, this strategy may turn into violence or incapacitation, which are more dangerous forms of passivity (Schiff, Schiff, 1971).

Relatively less often, the respondents admitted to using violence (mean 6.68, median 6 , mode 3 ). Nonetheless, at this point, it is worth noting a potential interfering variable that may have appeared in the research. It should be acknowledged that the research was of a declarative nature - the respondents had to determine their level of identification with specific statements. In the case of violence, some results could have been distorted because of the nature of the statements, simultaneously accompanied by the respondents' awareness concerning social evaluation of a given behaviour. Bearing in mind this distorting variable, it needs to be emphasized that the learners also recognize to a certain extent the most destructive manifestations of passivity both in the area of violence and incapacitation. This fact is significant because these forms of passivity bring the most serious, sometimes life-threatening, consequences. Both violence and incapacitation arise 
when the energy accumulated earlier in other forms of passivity is discharged (Schiff, 1975). We can say that violence sends this energy outside (for example, through some act of vandalism), and incapacitation directs it inside, thus, it is a kind of autoagression. Violence and incapacitation are the last resort in passive behaviours. The person who uses them completely resigns from responsibility for his/her thinking and acting.

After analysing the general scope of passive strategy use by learners at the threshold of the second stage of education, gender differences in this area will be discussed. In order to identify the differences, the data has been analysed with the use of Mann-Whitney $\mathrm{U}$ test (with tie correction), assuming the significance of the results at the level of $\mathrm{p}<0.05$.

In the case of almost all passive strategies, significant gender differences have been indicated, which is displayed in the table below.

Table 5.

Gender differences in the scope of passive strategy use ( $\left.N=2172 ; N_{F}=1126, N_{M}=1046\right)$

\begin{tabular}{lccccc}
\hline Passive strategy & $\mathbf{U}$ & $\mathbf{Z}$ & $\mathbf{p}$ & $\begin{array}{c}\mathbf{Z} \\
\text { with tie correction }\end{array}$ & $\mathbf{p}$ \\
\hline Doing nothing & 491801.5 & -6.65 & 0.00 & -6.68 & 0.00 \\
\hline Overadaptation & 524640.5 & -4.40 & 0.00 & -4.42 & 0.00 \\
\hline Agitation & 503899.0 & -5.821 & 0.00 & -5.85 & 0.00 \\
\hline Violence & 474070.5 & -7.86 & 0.00 & -7.93 & 0.00 \\
\hline Incapacitation & 572560.5 & 1.12 & 0.26 & 1.12 & 0.26 \\
\hline
\end{tabular}

The comparison of boys and girls shows thatthe only exception is the incapacitation strategy, where gender differenceshave not been noticed, which means that both the girls and the boys apply this strategy to their functioning to the same extent. In other cases, differences can be identified, which means that the data should be further analysed to determine the quality of the differentiation. The indicators presented above show that the most important gender differences concern firstly, the strategy of violence and secondly, of doing nothing. It should be noted that these are strategies on the opposite ends of the continuum of destructiveness. Consequently, the identification of gender interdependences in their use appears to be important.

In Figure 1, gender differences in using the doing nothing strategy have been illustrated. 


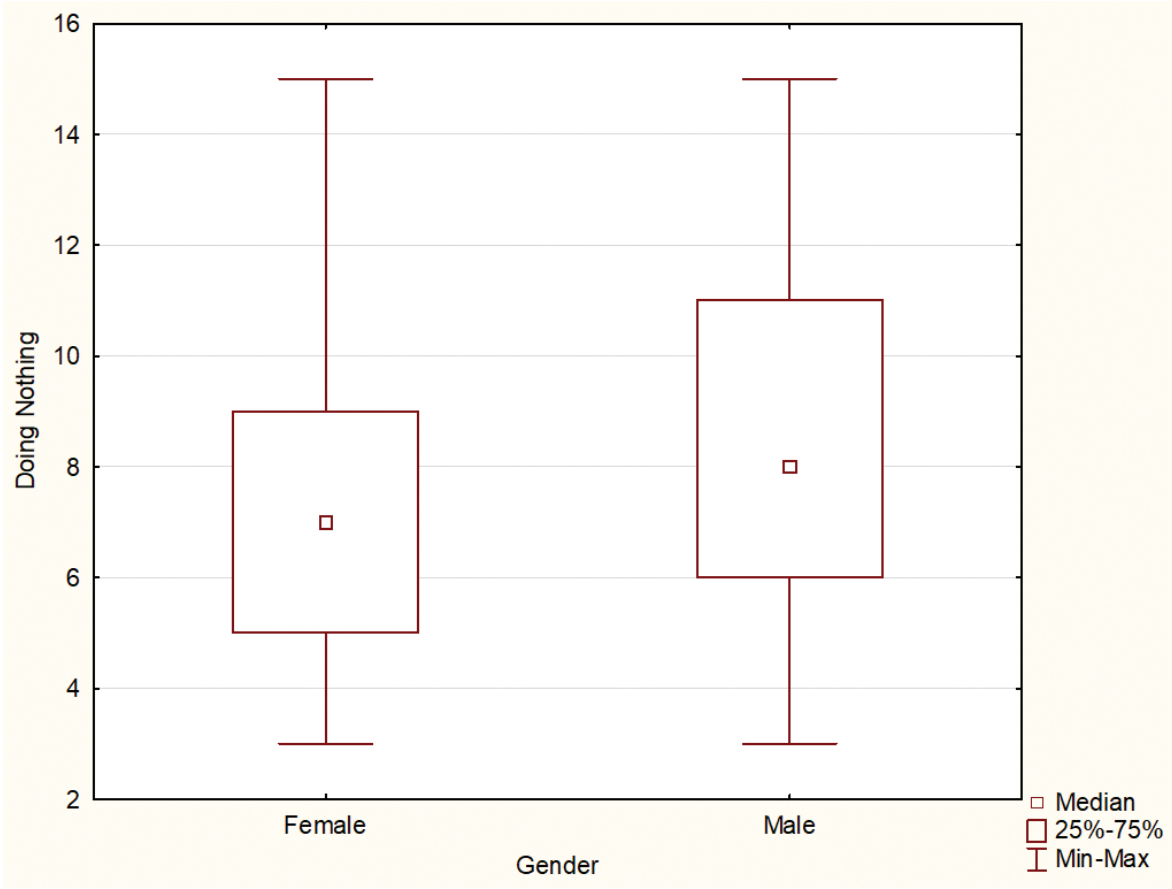

Figure 1. Gender differences in using the doing nothing strategy $(\mathrm{N}=2172 ; \mathrm{NF}=1126, \mathrm{NM}=1046)$

The analysis indicates that the boys recognize in themselves the doing nothing strategy in a higher degree than the girls. The median obtained by them in the study is 8 , and the values between the first and third quartiles are in the range between 6 and 11 . For the girls, the respective values are lower - the median is 7, the first quartile (Q1) is 5, and the third (Q3) 9. Mann-Whitney U test applied previously indicates a significant difference between the two groups. This means that the surveyed boys aged 10-12 are more likely to give up action in the face of a problem, trying to transfer responsibility for their own inertia to the environment. At the same time, it is important to note that although the research focuses mainly on gender differences, a deeper analysis indicates a statistically significant difference in the use of doing nothing also in the case of age. (Mann-Whitney $\mathrm{U}$ test, grouping variable: grade 4/5, $\mathrm{p}<0.05$; $\mathrm{U}=470259.5 ; \mathrm{Z}=-5.01$; $\mathrm{Z}$ with tie correction $=-5.04$ ). Moreover, the analysis of variable distributions indicates that the older the learners, the more often they use the discussed strategy.

Slightly smaller differences are revealed in the case of the overadaptation strategy, as shown in Figure 2. 


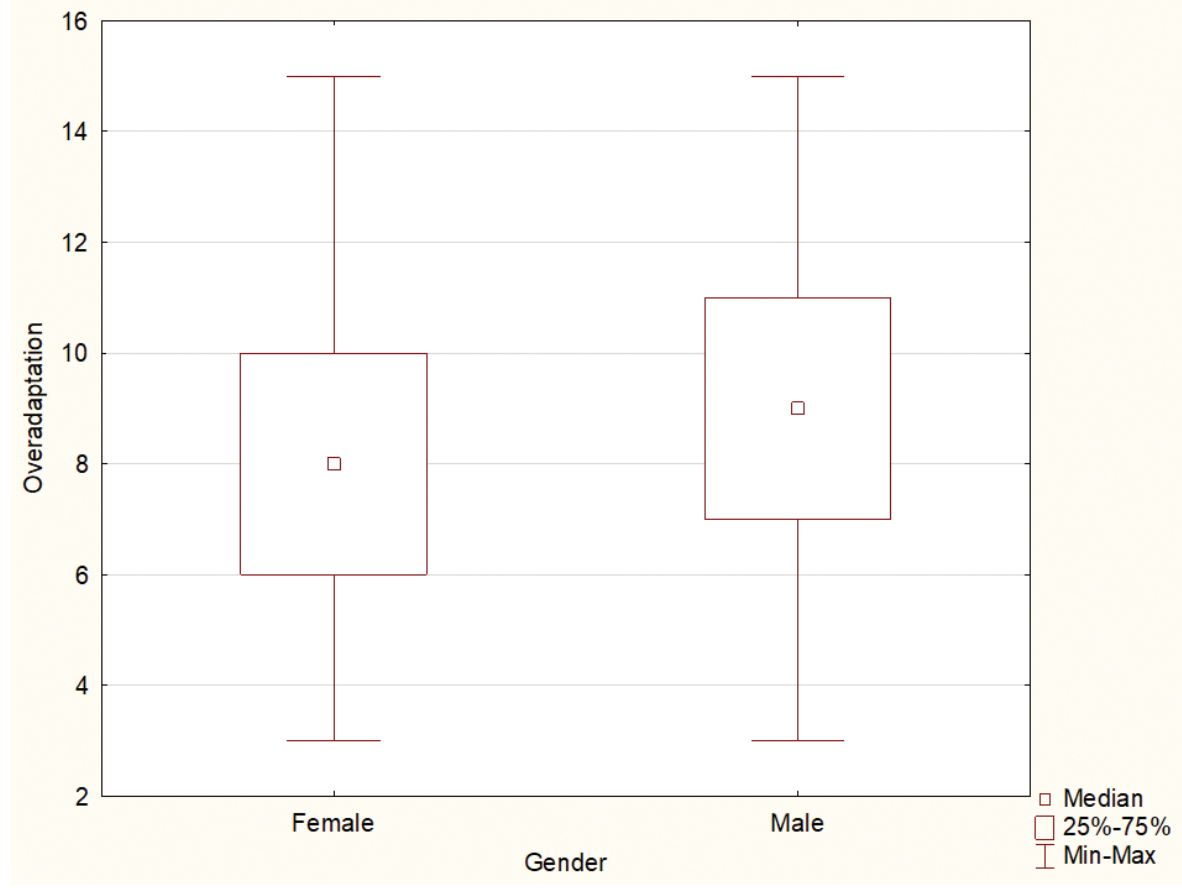

Figure 2. Gender differences in using the overadaptation strategy $(\mathrm{N}=2172 ; \mathrm{NF}=1126, \mathrm{NM}=1046)$

Once again the boys recognize its presence in a slightly higher degree than the girls. Differences in the range of the quartiles I., II.and III. are 1 in each case. For the girls, they are located in the values of $6(\mathrm{Q} 1), 8(\mathrm{Q} 2 / \mathrm{Me})$ and $10(\mathrm{Q} 3)$. In the case of the boys, however, they take higher values of $7(\mathrm{Q} 1), 9$ (Q2/Me), 11 (Q3), which means that the boys recognize the need for excessive adaptation to the expectations of the environment to a greater extent. They also tend to identify with the goals set for them to a smaller degree. Nonetheless, it should be noted that the research was conducted in schools, which, as typical educational institutions, to a large extent determine the appearance of external goals which result from curricula. Therefore, the motive behind lack of this identification among learners, especially among boys, remains an open question.

In the case of overadaptation, no differences connected with age have been revealed, which implies that pupils in grades 4 and 5 identify with this passive strategy to the same extent.

The differences displayed in Figure 3.concern the agitation strategy. 


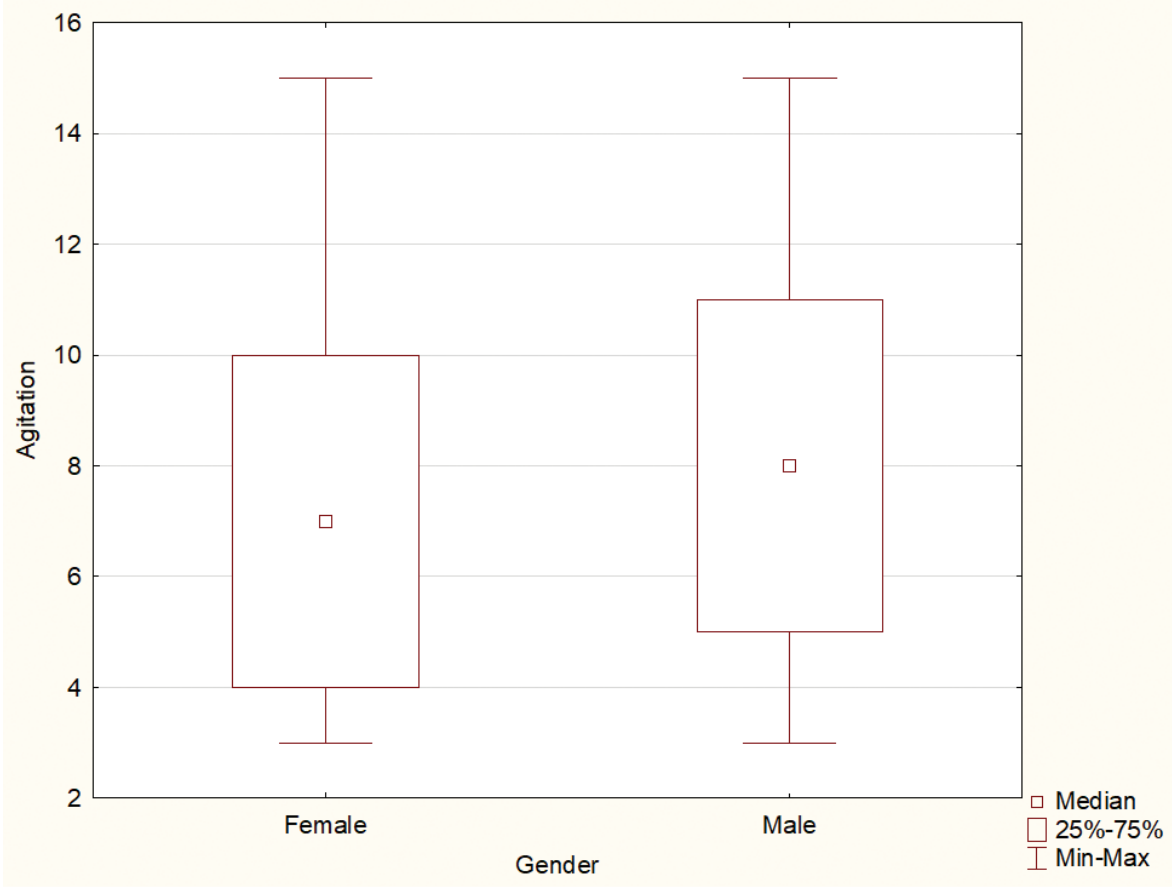

Figure 3. Gender differences in using the agitation strategy $(\mathrm{N}=2172 ; \mathrm{NF}=1126, \mathrm{NM}=1046)$

The results concerning agitation are similar to those of overadaptation since the boys dominate again. The median is slightly lower, in this case -7 for the girls and 8 for the boys. Additionally, there is a larger spread of the results in the range of $25-75 \%$ of the responses, i.e. those between Q1 and Q3. This implies on the one hand, that the learners identify with agitation in a slightly lower degree than with overadaptation and, on the other hand, due to the spread of the results, this strategy may not be sufficiently clear for them and therefore difficult to identify. This fact is indirectly confirmed by the results obtained in terms of age differences. Again, the scope of using agitation increases with age and is statistically significant (Mann-Whitney $U$ test, grouping variable: grade $4 / 5$; $\mathrm{p}<0.05, \mathrm{U}=449416.0, \mathrm{Z}=-6.50, \mathrm{Z}$ with tie correction $=-6.53$ ). Increasing recognisability of functioning in this strategy can stem from the development of the so-called Adult who is, in terms of transactional analysis, the most objective and independent part of human personality, which develops throughout a person's life on the basis of experience. The age of 10-12 is the first moment of intense development of independence and selfdetermination. On the other hand, it is difficult not to accept a less optimistic hypothesis assuming that the environment in which learners function causes that with age they enter higher levels of passivity. Confirmation of the accuracy of these hypotheses should be found in subsequent studies. 
The biggest difference connected with gender and concerning functioning in specific passive strategies has been identified in the case of aggression, which has been illustrated in Figure 4.

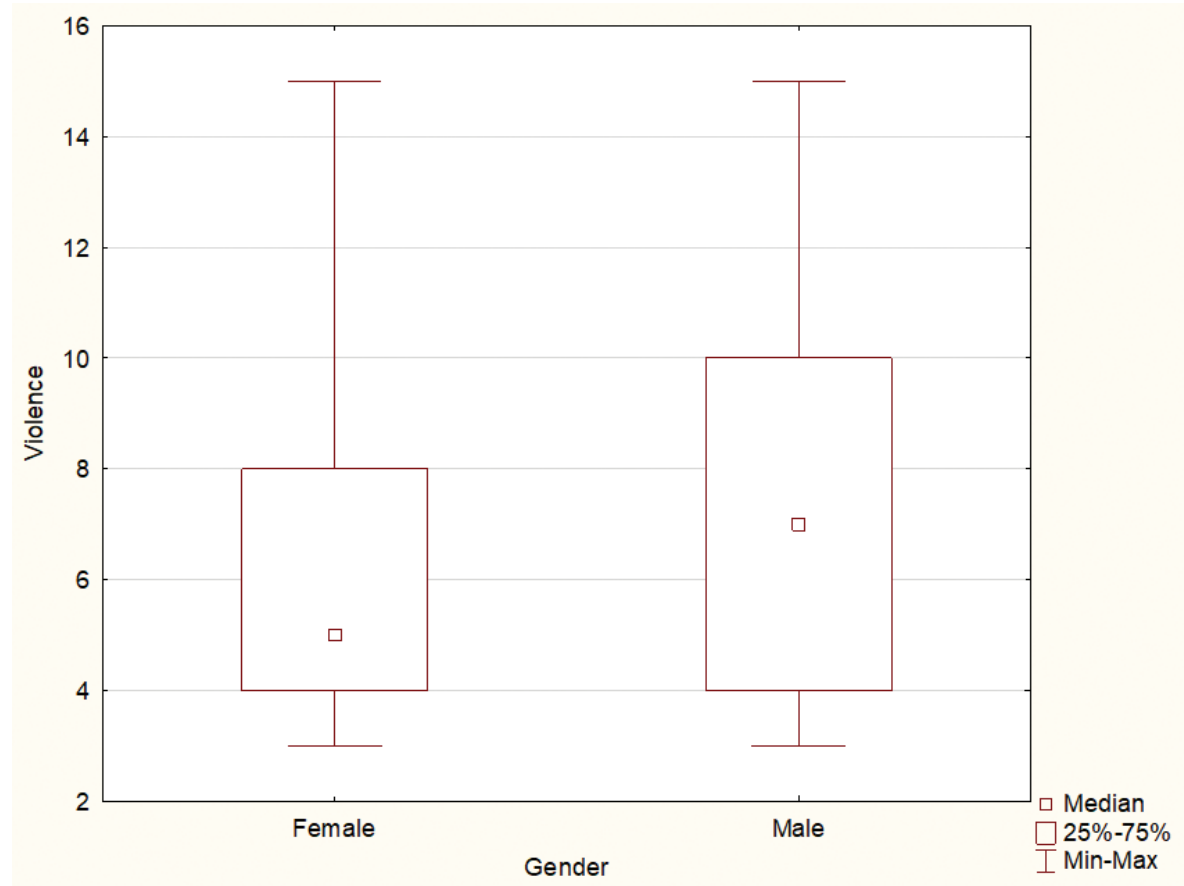

Figure 4. Gender differences in using the violence strategy $(\mathrm{N}=2172 ; \mathrm{NF}=1126, \mathrm{NM}=1046)$

The dominant position of the boys in the use of this strategy can be clearly seen. Nonetheless, it should be noted that it is also the strategy that the learners generally have recognized in themselves in the lowest degree. Considering the diversity of the results in relation to gender, it can be seen that $25 \%$ of the responses in both groups are below level 4, which is an optimistic result since it is low on the scale that ranges from 0 to 15. The median strongly differentiates the girls and the boys. For the female learners, it is 5 and for the male learners, it is 7. Hence, there is a difference of two degrees on the scale. In addition, the value of the third quartile (Q3) strongly differentiates the groups - the girls' result is 8 , and the boys' amounts to 10 . Thus, it can be seen that these are mainly the boys who admit that they use this most dangerous passive strategy. Interestingly, in the case of violence, a statistically significant difference in its use in the context of age has been identified (Mann-Whitney $U$ test, grouping variable: grade $4 / 5 ; p<0.05$, $\mathrm{U}=481245.0 ; \mathrm{Z}=-4.23 ; \mathrm{Z}$ with tie correction $=-4.26$ ). The median of the learners' responses is identical in both groups and amounts to 6 . However, the groups are differentiated by the spread of the responses. The value of the third quartile (Q3) in the case of 
the fourth grade students is 8 , and in the case of the fifth grade students, it amounts to 10 , which indicates that again the scope of using this passive strategy increases with age.

Summing up, it can be observed that in all the cases of identifying gender differences in the use of passive strategies, the boys were more likely to trace them in their functioning. Incapacitation is the only strategy for which gender differences have not been found. At the same time, for most strategies (doing nothing, agitation, violence), age differences have also been revealed. In each case, older students (grade 5) have recognized in themselves passive functioning to a greater extent. Thus, it is worth considering possible causes of the described dependencies. In order to do it, referring to the assumptions of the basic concept appears to be necessary.

\section{Most frequent sources of learners' passivity according to the assumptions of transactional analysis}

Transactional analysis assumes that we learn the patterns of passive behaviours in childhood. They become established in human functioning as specific script records. The script is a hidden scenario of human life, which we acquire in early childhood and in accordance with which we operate in adulthood (Berne, 2005). It contains opinions about people, the world and ourselves, as well as specific strategies of acting in situations that coincide in some way with those we experienced in the past. In this approach, passivity is a certain area of script and since it is based on early-childhood records, it can be difficult to eliminate.

The concept of transactional analysis usually assumes that the first script records are acquired by people already in the prenatal period, when they are experiencing a specific emotional contact with the mother. Then, after birth, they learn about the surrounding world and construct a picture of themselves on the basis of the way in which they are taken care of, the parents' reactions to them, their crying and their calls, the manner the parents address them, etc. At a slightly older age, all that is accompanied by direct messages from significant people (usually parents and close relatives), which describe the world, other people, and provide evaluative opinions to children. At some point, young people reject some of these messages, but they accept others as real (the so-called moment of script decision) and start to function in accordance with these beliefs. Then, the so-called frames of reference and existential life positions are formed. The way of functioning in the face of a problem situation, including passive behaviours, depends to a great extent on them. The reference framework is constituted by a specific image of the world, a kind of cognitive filter that determines things to which a person pays attention, which he notices in the world, and which he/she discounts (Stewart, Joines, 2009).Life position, in turn, is a specific opinion about oneself and other people in the world. The concept of transactional analysis assumes that there are four such positions, only one of 
which is fully healthy (Stewart, Joines, 2009). The following positions are distinguished: "I am OK. You are OK.", "I am not OK. You are OK.", "I am OK. You are not OK.", "I am not OK. You are not OK." Obviously, the most positive and constructive is the first position, which assumes that "both I myself and people around me" are good by definition.This is the main philosophical assumption of transactional analysis, which does not involve an attitude that will re-evaluate both people's and one's own capabilities and resources. People, whose position is "I am OK, You are OK." are able to evaluate themselves and other people realistically, look at them in a humanistic and holistic way. However, development of such an attitude is not easy since it requires growing up in a supporting and accepting environment.

The other three life positions make people discount, that is neglect and disregard certain important facts. People possessing the position "I am not OK. You are OK." cease to see their own potential and diminish their abilities, excessively looking for support in the environment. The position "I am OK. You are not OK." is connected with overrating one's own potential and simultaneous lack of faith in other people. People who possess this position have a strong need to dominate and control others and to impose their own solutions. Finally, the position "I am not OK. You are not OK." is most destructive because it connects lack of faith in yourself with lack of faith in others, which results in depression, a sense of meaninglessness of existence, and may even lead to a suicide.

Therefore, the way in which people react to emerging problem situations depends on how they learned to perceive the world (their frame of reference), themselves and other people (their life position) in early childhood. What is more, it seems that the position "I am OK. You are OK." will be conducive to effective coping with problems, while other positions will accompany specific passive strategies.

\section{Conclusions for education and upbringing}

The presented research results indicating the scope of passivity use by children learning in the 4th and 5th grades of Polish primary schools, allow for formulating a few educational recommendations in accordance with the concept of transactional analysis. Applying these recommendations at the youngest age of a child's life gives a chance to eliminate - or at least minimize - passive behaviours.

Therefore, the child's early education in terms of openness, cognitive curiosity and building a positive image of himself/herself and the world seem to be extremely important. Using the terminology of transactional analysis, it is essential to stimulate the development of the Adult and to activate the Free Child, mainly in the area of the Little Professor. The Adultis held accountable for the real view of reality and the processing of information coming to people from the outside and from their other ego areas, which implies that the Adult is responsible for the realistic view of himself/herself and other 
people. He/she is able to identify resources and limitations, analyse available information, recognise own emotions and feelings.

Nonetheless, the development of the Adult requires contact with another Adult, that is, with an interaction partner, who will provide a model. For this reason, dominance is required in preparing to the Adult-Adult relationship. Educational methods, in this case, should be based on questions (tutorial dialogue) and on following the child, which will help to eliminate discounting, and thus, to gain a wider perspective on the world, people and oneself. In addition, it is extremely important to train children in the ability to recognize their own emotions and needs, as well as in the skill of setting goals.

Referring to the already mentioned Free Child in the area of the Little Professor, this is the part of the human personality that is able to react freely to the emerging situation and which can be compared to the Freudian Id. It is the most emotional ego part thanks to which people are able to experience the world, reacting with happiness, joy, but also with anger, sadness, etc. without the need to rationally analyse the situation. The area of the Little Professor, in turn, allows for discovering and learning on the basis of intuition and something that can be called childish curiosity for searching and passion. Therefore, it is a form of cognition that provides most joy and is most creative at the same time, frequently due to unconventional ways of acting. It is worth noting that the education system, as well as many educational activities organised in families outside the school, hinder this natural spontaneity of children, killing creativity as a consequence. Therefore, methods of working with children based on following them and creating space for free exploration based on current needs and cognitive curiosity of the child should be promoted. However, such forms of work should always be accompanied by self-analysis concerning one's own feelings, needs and assessment of one's own actions. Consequently the development of the Adult is fostered.

Considering what has been said about the sources of passivity in terms of transactional analysis, the dependencies presented in Table 5 and Figures 1 to 4 should be recalled. They indicate a greater range of passive strategy use by the boys than the girls. Search for specific reasons of such a situation could be the aim of further studies. Although the present research has been purely exploratory and diagnostic, some hypotheses can be posed:

1. The sources of passivity should be sought in script records and related to them early educational actions. Above, two areas of human personality which are particularly important for counteracting passive behaviours have been indicated. They perform their specific tasks in this regard.

a. It can be observed that natural energy and intuitive intentions in the case of boys and girls are usually slightly different (or differently stimulated and strengthened). Social image perceives girls as quieter, fond of more stationary activities, in contrast to boys, who like movement and physical activity. Further research could involve investigating attitudes and reactions of parents to children's own activities. It seems, however, that stationary activities are easier to accept 
and more likely to gain the approval of the environment and thus, positive reinforcement. Hampering the natural activity of boys may in turn inhibit their Free Child in terms of natural cognitive curiosity.

b. In the case of the Adult, the tasks involve recognition of emotions and feelings. It seems that autoanalytic skills in this area are crucial for abandoning passivity and attempting to deal with the problem efficiently. Again, the reasons for the greater use of passive strategies by boys can be sought in early educational influences and interactions. Emotionality of boys is sometimes inhibited - they often hear from their parents: "boys don't cry", "you are a man, you can't be afraid". Consequently, emotions may be discounted and children may lose the ability to recognize them in themselves.

2. Moreover, the differences in the use of passivity in relation to age should be taken into account.In this case, it can be concluded that the older the learners, the more passivity they use. The present article indicates only specific trends in this area, which is conditioned by the choice of the research sample, whose age diversity was low. Nonetheless, significant differences which were revealed may indicate a low degree of identification of Polish learners (especially boys) with educational goals. Their objectives do not involve acquisition of specific knowledge and skills, but only getting positive assessment. This kind of behaviour seems to stem from overadaptation, which is the passive strategy most often indicated by the subjects of the research. Its characteristic feature is apparent realisation of goals set for an individual. At the moment of obtaining positive assessment, the learner is usually praised by the teacher, which creates an impression of fulfilling the duty. At the same time, however, to a great extent it is not related to acquiring knowledge and skills that were assumed in the process of constructing the curriculum, which indicates the need to find a way to establish such relationships with learners, due to which they would be able to identify with the educational goals set for them. To achieve this, understanding and integration of what is taught and why it is taught are necessary. Transactional analysis seems to be a tool that can be useful also in this case.

\section{Summing up}

The present article has shown possibilities of diagnosing student passivity in the perspective of transactional analysis. Moreover, apart from discussing the scope and types of passivity, it has referred to theoretical sources of its existence. Although formulating specific pedagogical recommendations requires more in-depth studies, already at the present moment,it is advisable to use the assumptions of transactional analysis and from an early age, it is desirable to support children's skills in learning about themselves and, 
at the same time, to allow them to explore the world freely. Such educational influences have a chance to shape a creative person, who will effectively deal with problem situations without having to resort to passive strategies.

It should be noted that such actions have already been implemented in the world to a certain extent. Some trainings for students based on the assumptions of transactional analysis are conducted in Macomb Community College in Detroit (Gaft, Moore Brown $\mathrm{El}$, 2004). There are schools in London that use the concept both for teacher training and as a method of working with students. The Institute of Developmental TA (IDTA) in that city established even a prestigious award for children and adolescents for proficiency in the area of TA - TA Proficiency Award for Children \& Young People (TAPACY) (Barrow, 2007). The first steps have also been taken in this area in Poland. As part of the professional training of teachers (as well as students of psychoprophylaxis) at the Jan Dlugosz University in Czestochowa, classes in transactional analysis are conducted. Teaching methods based on the assumptions of the concept are also used in workshops conducted by the members of the Educational Transactional Analysis Research Team. Moreover, since the beginning of the school year 2018/2019, a primary school and a kindergarten in Sosnowiec (Poland) have been implementing an experimental programme concerning the development of children's social skills according to the assumptions of the concept ${ }^{4}$. The programme aims at supporting communication skills, recognizing one's own feelings and emotions as well as feelings and emotions of other people (empathy), building a positive self-image and developing problem solving skills (Pierzchała, 2018). In the future, such actions have a chance to minimize learners' passive functioning, supporting their autonomy and resilience to conflict situations at the same time.

\section{References}

Barrow, G., Bradshaw, E., Newton, T. (2001). Improving Behaviour and Raising Self-Esteem in the Classroom. A Practical Guide to Using Transactional Analysis. London, UK: David Fulton Publishers

Barrow, G. (2007). Transactional Analysis, Pastoral Care and Education. Personal Care in Education,25(1), 21-25. https://doi.org/10.1111/j.1468-0122.2007.00396.x

Barrow, G., Newton, T. (eds.) (2004). Walking the Talk. How Transactional Analysis is Improving Behaviour and Raising Self-esteem. London, UK: David Fulton Publishers.

Barrow, G., Newton, T. (eds.) (2015). Educational Transactional Analysis: An international guide to theory and practice. Abingdon, UK: Routledge

Berne, E. (2005). Dzień dobry... i co dalej? Poznań: REBIS (Polish issue of: Berne E. (1969). What do you say after you say hallo? New York: Corgi)

4 More about the project can be found on: https://eat.ujd.edu.pl/ump (retrieved: 23.10.2018) 
Berne, E. (2008). Transactional Analysis in Psychotherapy. London: Souvenir Press (Educational \& Academic) Ltd.

Clarke, J.I. (1981). Differences Between Special Field and Clinical Groups. Transactional Analysis Journal, 11(2), 169-170. https://doi.org/10.1177/036215378101100214

Emmerton, N., Newton, T. (2004).The Journey of Educational Transactional Analysis from Beginnings to the Present.Transactional Analysis Journal, 34(3), 283-291. https://doi. org/10.1177/036215370403400314

Frazier, T.L. (1971). The Application of Transactional Analysis Principles in the Classroom of a Correctional School, Transactional Analysis Journal, 1(4), 214-218. https://doi. org/10.1177/036215377100100405

Gaft, S., El Moore Brown, C. (2004). Transactional Analysis in the College Classroom. Transactional Analysis Journal,34 (3), 243-248. https://doi.org/10.1177/036215370403400308

Gębuś, D., Pierzchała, A. (2016). Twórczy nauczyciele, pomysłowi uczniowie. Osobowościowe korelaty kreatywności nauczycieli w perspektywie analizy transakcyjnej. (English: Creative Teachers, Ingenious Students. Personality Correlates of Teachers' Creativity in the Perspective of Transactional Analysis) Częstochowa: Wydawnictwoim. Stanisława Podobińskiego Akademiiim. Jana Długosza w Częstochowie.

Jagieła, J. (2018). Edukacyjna analiza transakcyjna na tle innych orientacji psycho pedagogicznych. (English: Educational Transactional Analysis Against the Background of Other Psychopedagogical Orientations) Częstochowa: Wydawnictwoim. S. Podobińskiego Uniwersytetu HumanistycznoPrzyrodniczegoim. J. Długosza w Częstochowie

James, D., Jongeward D. (2003). Narodzić się, by wygrać. Analiza transakcyjna na co dzień. Poznań: REBIS (Original title: Born to Win)

Lerkkanen, M., Temple, S. (2004).Student Teachers' Professional and Personal Development Through Academic Study of Educational Transactional Analysis. Transactional Analysis Journal, 34(3), 253-271. https://doi.org/10.1177/036215370403400311

Łęski, Z. (2016). Duch w maszynie... Kim jest dla nas komputer? Charakterystyka relacji w jezyku analizy transakcyjnej. (English:A Ghost in the Machine... Who Is the Computer for Us? Characterising the Relationship in the Perspective of Transactional Analysis) Częstochowa: Wydawnictwoim. Stanisława Podobińskiego Akademiiim. Jana Długosza w Częstochowie

Łęski, Z. (2018). Nowe technologie - nowe czasy - nowe pokolenia. Charakterystyka młodych użytkowników mediów z perspektywy analizy transakcyjnej. (English: New Technologies - New Times - New Generations. Characteristics of Young Users of the New Media from the Perspective of Transactional Analysis) Częstochowa: Wydawnictwoim. S. Podobińskiego Uniwersytetu Humanistyczno-Przyrodniczegoim. J. Długosza w Częstochowie.

Mellor, K., Schiff, E. (1975). Discounting.Transactional Analysis Journal, 5(3), 295-302.https:// doi.org/10.1177/036215377500500321

Pierzchała, A. (2013). Pasywność w szkole.Diagnoza zjawiska z punktu widzenia analizy transakcyjnej. (English: School passivity. Diagnosis of the phenomenon from the transactional 
analysis point of view). Częstochowa: Wydawnictwoim. Stanisława Podobińskiego Akademiiim. Jana Długosza w Częstochowie.

Pierzchała, A. (2018). Uniwersytet Małego Profesora, czyli analiza transakcyjna w przedszkolu i szkole podstawowej. (English:The Little Professor's University, or transactional analysis in the kindergarten and primary school) Edukacyjna Analiza Transakcyjna, 7, 277-278. https:// doi.org/10.16926/eat.2018.07.17

Sarnat-Ciastko, A., Gębuś, D., Zalewski, Z. (2018). „Wychować człowieka mądrego”. Raport końcowy z badańe waluacyjnych ogólnopolskiego projektu wdrażania tutoringu szkolnego. (English:"Raise a Wise Man".Final Report on Evaluation Studies of a Nationwide School Tutoring Implementation Project). Częstochowa: Wydawnictwoim. Stanisława Podobińskiego Uniwersytetu Humanistyczno-Przyrodniczegoim. Jana Długosza w Częstochowie.

Schiff, A. W., Schiff, J. L. (1971). Passivity. Transactional Analysis Journal, 1(1), 71-78. https://doi. org/10.1177/036215377100100114

Schiff, J. \& others (1975). Cathexis Reader. New York: Harper \& Row, Publisher, Inc.

Sills, Ch., Fish, S., Lapworth, P. (1999). Pomoc psychologiczna w ujęciu Gestalt. (English: Psychological Help in Terms of Gestalt) Warszawa: Instytut Psychologii Zdrowia - Polskie Towarzystwo Psychologiczne

Soles, S. (1963). Social dynamics.A study of classroom games - Progress report.Transactional Analysis Bulletin, 2(8), 97.

Stewart, I., Joines, V. (2009). TA Today. A New Introduction to Transactional Analysis. Nottingham, England and Chapel Hill, North Carolina, USA: Lifespace Publishing.

Widawska, E. (2016). Ku czemu wychowywać ma szkoła? Refleksja w oparciu o model analizy transakcyjnej. (English: What Should Be The Direction of Upbringing at School? Reflection based on the model of transactional analysis). Edukacyjna Analiza Transakcyjna, 5, 93-109. https://doi.org/10.16926/eat.2016.05.06

\section{Pasyvumo strategijų panaudojimas 10-12 metų amžiaus moksleivių grupejje iš transakcinès analizès perspektyvos}

\section{Anna Pierzchała}

Jano Dlugoszo universitetas, Pedagogikos fakultetas, Pedagogikos institutas, Švietimo transakcinès analizės tyrimo grupè, Waszyngtona g. 4/8, 42-200, Čenstochova, Lenkija, a.pierzchala@ujd.edu.pl

\section{Santrauka}

Šiuolaikinè mokykla susiduria su daugeliu socialinių ir ekonominių sunkumų, kurie mažina jos veiksmingumą ir neigiamai veikia švietimo veiklos kokybę. Pasyvumas susijęs su socialinėmis 
problemomis, kurios daro ịtaką ịvairioms pedagoginès veiklos sritims, taip pat mokinių ir mokytojų santykiams. Straipsnyje apžvelgiami jaunimo pasyvumo mokyklos aplinkoje tyrimo rezultatai. Pasyvumas čia apima vieną iš psichoterapinių koncepcijų prielaidų - transakcinę analizę. Tai suprantama kaip efektyvumo stoka sprendžiant probleminę situaciją, kuri gali pasireikšti keliomis strategijomis: neveikimo, prisitaikèliškumo, agitacijos, neveiksmingumo ar smurto.

Tyrimo tikslas - išsiaiškinti pasyvumo strategijos paplitimą tarp 10-12 metų amžiaus Lenkijos mokinių ir jos taikymo sritį. Pateikti rezultatai yra Lenkijos nacionalinès švietimo ministerijos finansuojamo projekto „Auginkime išminčių“ (projektą igyvendina Atviro švietimo draugija, bendradarbiaujanti su Jano Dlugoszo universitetu Čenstochovoje, Lenkija) dalis. Išvados yra susijusios su jaunimo pasyvumo reiškinio paplitimo mastu, atitinkamų strategijų naudojimo apimtimi ir tokių situacijų priežasčių paieška šeimos santykių srityje.

Esminiai žodžiai: transakciné analizè, pasyvumas, neveikimas, prisitaikèliškumas, agitacija, neveiksmingumas, smurtas.

Gauta 201902 20/ Received 20022019

Priimta 20190715 / Accepted 15072019 